\title{
Corporate Social Responsibility Disclosure, Leverage, and Firm Value: The Moderating Role of Profitability
}

\author{
Irwansyah $^{\# 1}$, Yoremia Lestari Ginting ${ }^{\# 2}$, Anisa Kusumawardani ${ }^{\# 3}$, Juspita Erdiyanti ${ }^{\# 4}$ \\ ${ }^{\#}$ Faculty of Economics and Business, Mulawarman University \\ Samarinda, Indonesia \\ 1irwansyahefeb. unmul.ac.id
}

\begin{abstract}
Corporate Social Responsibility (CSR) is a strategic investment that brings many economic benefits for the company in the long term. Many benefits obtained by the company with the implementation of CSR, among other products increasingly favored by consumers and companies interested investors. CSR can be used as a new marketing tool for the company, if it is implemented continuously. Therefore, CSR plays an important role in increasing the value of the company as a result of increased sales of the company by conducting various social activities in the surrounding environment. This paper investigates the effects of Corporate Social Responsibility Disclosure (CSRD) and Leverage on Firm Value with Profitability as Moderating Variable. Analysis tool used in this study is the Moderated Regression Analysis (MRA) and Multiple Linear Regression analysis. There were 68 firm-years of Indonesia listed companies with CSR reports from 2012 to 2015. The paper found that leverage influences the firm value. However, CSRD did not affect the firm value. In addition, profitability as moderating variable was proven and capable of strengthening the relationship between corporate social responsibilities with firm value and strengthens the relations between leverage with firm value. The findings have important implications for practitioners with respect to CSR disclosure in addressing firm value.
\end{abstract}

Keywords - corporate social responsibility, firm value, leverage, profitability

\section{INTRODUCTION}

In general, the company's performance is assessed from the maximum profit level, this will make investors interested in investing in the company. The choice of investment in the consumer goods sector could be an alternative when in other sector companies still showed weakening performance that can be seen from the movement of its shares down significantly [1]. In contrast to the consumer goods sector which some years earlier had its share movement down but not so significantly, because the company was known to be resistant to the crisis.
As many companies grow, so at the same time social inequalities and environmental damage are likely to occur, so there is an awareness to reduce this negative impact [2]. Many private companies are now developing what is called Corporate Social Responsibility (CSR). CSR is a strategic investment that brings many economic benefits or blessings that are abundant for the company in the long term [3].

The issue of CSR in Indonesia has been growing for a long time, but the attention and its implementation has only started to develop in recent years and is done by certain companies only [4]. In addition, Law no. 40 Year 2007 regarding Limited Liability Company, stating that companies whose activities related to Natural Resources are required to carry out social and environmental responsibility.

CSR is no longer faced with responsibilities based on the single bottom line, but should stand on the triple bottom lines. Here the bottom lines other than financially are also social and environmental, because the financial condition alone is not enough to guarantee the value of the company to grow sustainably. Company sustainability will only be ensured if the company takes into account the social and environmental dimensions. CSR implemented in various environmental management system and certification program in Indonesia. For example, ISO 14001 certification is used for Environmental Management System or ISO 50001 for Energy Management System. The companies take environmental permits, air and water pollution control, hazardous waste management, and monitoring of environmental parameters in accordance with applicable regulations. Beside 
CSR disclosure, another factor that can affect the value of a company is leverage. Funding sources within the company can be obtained from internal companies in the form of retained earnings and depreciation expense, then from external company in the form of debt or new stocks issued.

This study refers to [5] which previously studied about the influence of corporate social responsibility toward firm value with profitability as moderating variable in $2009-2011$ period. This study adds independent variable that is leverage because besides the problem of corporate social responsibility, leverage also influence the firm value. Furthermore, profitability is used as a moderating variable in this study because profitability is one of the company's measuring tools to determine the effectiveness of company performance. The greater the profitability of a company, the greater the level of profit achieved by the company and the better the company's position in the use of assets [6].

Handriyani [5] stated that the influence of corporate social responsibility towards firm value with profitability as moderating variable shows that profitability as moderating variable was not able to strengthen relationship of CSR disclosure and corporate value. Meanwhile, in contrast to the results of research [7] which showed that the profitability as a moderating variable found to strengthen the relationship between CSR with the company's value.

Based on the background description, the formulation of the problem in research are as follows:

- Does Corporate Social Responsibility Affect Firm Value?

- Does Leverage Affect Firm Value?

- Can Profitability strengthen or weaken the relationship between Corporate Social Responsibility and Firm Value?

- Can Profitability strengthen or weaken the relationship between Leverage and Firm Value?

The research objectives to be achieved are as follows:

- Examine the influence of Corporate Social Responsibility on Firm Value.

- Examine the effect of Leverage on Firm Value.
- Examine Profitability can strengthen or weaken the relationship between Corporate Social Responsibility with Firm Value.

- Examine Profitability can strengthen or weaken the relationship between Leverage and the Firm Value.

\section{THEORETICAL AND DEVELOPMENT HYPOTHESIS}

Based on stakeholder theory, company is not an entity that only operates for its own sake but must provide benefits for its stakeholders [2]. Which means that the success of a company depends heavily on its ability to balance the diverse interests of shareholders or stakeholders [3]. According to the legitimacy theory argues that companies must implement and disclose CSR activities to the maximum extent possible for corporate activities to be accepted by society as their stakeholders [8]. The disclosure is used to legitimize corporate activity in the eyes of the public, since CSR disclosure will indicate a company's compliance level. Therefore, in accordance to the signal theory, a company that predicts a low profit will tend to use low debt levels. High corporate debt will increase the likelihood that companies face financial difficulties. In other words, a rational company will increase debt if additional debt can increase profits [4].

\section{A. The Influence of Corporate Social Responsibility to Firm Value}

One of the company's main goals is to increase the value of the company. The value of the company will be guaranteed to grow sustainably if the company takes into account the economic, social and environmental dimensions. The dimensions are contained in the application of CSR disclosures conducted by the company as a form of awareness of the surrounding environment that will impact on the good image of the company among the community [7]. World Business Council for Sustainable Development (WBCSD) stated corporate social responsibility is defined as a business commitment to contribute to sustainable economic development, through collaboration with employees and their representatives, their families, local communities and the general public to improve the quality of life in a way that is beneficial for both business and development [9]. In line with the legitimacy theory that states that 
corporate social responsibility has the benefit to improve the company's reputation, maintain the image and strategy of the company.

H1: Corporate social responsibility affects the firm value

\section{B. The Effect of Leverage on Firm Value}

Leverage is a funding policy related to the company's decision to finance the company. One important factor in funding is leverage. Leverage indicates the extent to which the company finances its business by comparing its own funds that have been deposited with the loan amount from the creditors. Companies, that use debt, have liabilities on interest expense and principal cost of loans. The use of debt has a considerable risk of unpaid debt, so the use of debt should pay attention to the company's ability to generate profits [10].

In line with the signal theory that rational investors will see that the increase in corporate value comes from high debt usage. Thus, the investor may offer higher stock prices after the company issues debt to repurchase the outstanding shares.

H1: Leverage affects the firm value.

\section{The Effect of Profitability as A Moderation variable in relationship between CSR and Firm Value}

Understanding profitability as proposed by [4] that profitability is the ability of companies to generate profits by using resources owned companies, such as assets, capital, or sales company. Profitability is also defined as the end result of a number of policies and decisions made by the company [11]. Profitability is a factor that makes management free and flexible to disclose corporate social responsibility to shareholders [5]. So, the higher level of corporate profitability, the greater the disclosure of social information company [2].

Profitability can be an important consideration for investors in their investment decisions, as the larger dividend payout will save the capital cost, on the other hand the manager will increase his power and even increase his ownership due to dividend income as a result of high profit [2]. With the offer to get high profit results, is expected to attract investors in the investment.
H3: Profitability can moderate the relationship between corporate social responsibility and firm value.

\section{The Effect of Profitability as A Moderation variable in relationship between Leverage and Firm Value}

Profitability is the company's ability to generate profits over a period of time. The pecking order theory suggests that firms favour internal financing (funding from tangible enterprise operations results). Companies with high profitability certainly have larger internal funds than low-profit firms [4]. Obtained means the lower the need for foreign funds (debt) so that the lower leverage ratio [12].

Leverage is a funding policy related to the company's decision to finance the company. Companies that use debt have liabilities on interest expense and principal cost of loans. The use of debt has a considerable risk of unpaid debt, so the use of debt should pay attention to the company's ability to generate profits [10].

H4: Profitability can moderate the relationship between leverage and firm value.

\section{RESEARCH METHODS}

This study uses a quantitative approach to test those hypotheses. The analytical method used multiple linear regression analysis and Moderated Regression Analysis (MRA).

\section{A. Firm Value}

The value of the firm in this study is measured by using the ratio of price to book value (PBV). According to [11] the ratio of PBV can be calculated by the formula:

PBV $=($ Share Price per Share) $/$ (Book Value per Share)

While to calculate the book value per share can be calculated by the formula [8]:

Book Value Per Share $=($ Total Equity $) /($ Number of shares outstanding)

\section{B. CSR Disclosure}

Disclosure of CSR is an effort made by the company to show the public social activities undertaken by the company to be accepted by the community. Based on the checklist on the Global Reporting Initiatives (GRI) standard G3 Guidelines 
CSR calculations performed using dummy variables are:

Score 0 : if the company does not reveal an item on the questionnaire

Score 1 : if the company reveals an item on the questionnaire

The formula used as CSR calculation is as follows [5]:

$\mathrm{CSRDI}=(\Sigma \mathrm{Xij}) / \mathrm{nj}$

Information:

CSRDI : CSR Disclosure Index

$\mathrm{Nj} \quad$ : number of items for company $\mathrm{j}, \mathrm{nj} \leq 79$

$\mathrm{Xij} \quad$ : the number of items disclosed by the company

C. Leverage

Leverage in this research is measured using Debt to Equity Ratio (DER) ratio calculated by the formula:

DER $=($ Total Debt $) /($ Equity / Equity $)$

\section{Profitability}

In this study profitability as a moderating variable that affects the relationship of CSR disclosure and leverage to firm value. Profitability in this study is proportioned using Return on Assets (ROA).

ROA $=($ Net Profit After Tax $) /($ Total Assets $) \mathrm{x}$ $100 \%$

Data collection procedures used documentation and literature study. The literature sources are from journals, through the electronic media, such as soft file financial statements of the BEI's website www.idx.co.id, soft file sustainability report, and internet sites. The research population is all manufacturing companies listed on Indonesian Stock Exchange in the period 2012-2015. The number of sample is 37 companies and listed as a sub-sector company of consumer goods industry on year 2012-2015. Purposive sampling method used to select samples based on certain considerations in accordance with the research purpose. The criteria established are: (1). All companies listed in Indonesia Stock Exchange (BEI); (2). Publish a sustainability report that based on the GRI Guidelines in consecutive period 2012-2015; (3). The Company has a positive profit during 20122015.

\section{IV.RESULTS AND DISCUSSION}

TABLE

The results of statistical tests are as follows:

\begin{tabular}{|c|c|c|c|c|c|c|}
\hline \multirow{2}{*}{\multicolumn{2}{|c|}{ Model }} & \multicolumn{2}{|c|}{$\begin{array}{l}\text { Unstandardized } \\
\text { Coefficients }\end{array}$} & \multirow{2}{*}{\begin{tabular}{|l|}
$\begin{array}{l}\text { Standa } \\
\text { rdized } \\
\text { Coeffic } \\
\text { ients }\end{array}$ \\
Beta \\
\end{tabular}} & \multirow[t]{2}{*}{$\mathbf{t}$} & \multirow[t]{2}{*}{ Sig. } \\
\hline & & B & \begin{tabular}{|l|} 
Std. \\
Error
\end{tabular} & & & \\
\hline \multirow{5}{*}{1} & (Constant) & $-5,177$ & 3,870 & & $-1,338$ &, 186 \\
\hline & CSRDI & ,089 &, 120 & , 077 & ,745 & , 459 \\
\hline & DER & 12,027 & 2,307 & ,541 & 5,214 & ,000 \\
\hline & CSRDI*ROA & ,021 &, 008 & ,646 & 2,681 & 009 \\
\hline & DER*ROA & ,318 &, 128 & ,580 & 2,488 & 015 \\
\hline \multicolumn{2}{|l|}{$\mathrm{F}$} & \multicolumn{5}{|l|}{36,573} \\
\hline \multicolumn{2}{|c|}{ Sig. } & \multicolumn{5}{|l|}{0,000} \\
\hline \multicolumn{2}{|l|}{$\mathrm{R}$} & \multicolumn{5}{|l|}{0,795} \\
\hline \multicolumn{2}{|c|}{$\mathrm{R}^{2}$} & \multicolumn{5}{|l|}{0,632} \\
\hline \multicolumn{2}{|c|}{ Durbin-Watson } & \multicolumn{5}{|l|}{1,819} \\
\hline
\end{tabular}

The above table shows that, firstly, the corporate social responsibility disclosure index (CSRDI) had a positive and insignificant impact on the firm value (PBV). These results were consistent and support the research by [13], and [14]. This proves that the quality of CSR disclosure in the manufacturing industry sector of consumer goods industry listed on the BEI not fully follow the standards issued by GRI G3. This is not in line with the theory of legitimacy which states that companies must implement and disclose CSR activities as much as possible so that corporate activity can be accepted by society.

Secondly, leverage (DER) had a positive and significant impact on the firm value. This is consistent with research [10], and [15]. This proves that companies with low debt levels have a low risk whereas if the company has a high debt level it will be exposed to high risk. However, if the addition of corporate debt can increase the profit of the company, then it will give a positive signal to investors, which then investors will be interested to invest in the company. The results support the signal theory that rational investors will see that the increase in corporate value comes from high debt usage.

Thirdly, profitability had a positive effect as a moderating variable that strengthens the 
relationship between corporate social responsibility disclosure and firm value. The results of this study are consistent with the research conducted by [7] and [8]. This proves that when the profitability of the company increases then the company can reveal CSR activities as much as possible so as to enhance the reputation and good image of the company. The results of this study support the stakeholders' theory which states that the higher level of profitability achieved by the company the stronger the relationship of corporate social disclosure with the firm value. It means high levels of profitability can encourage companies to implement and disclose CSR activities so as to enhance the company's reputation.

Lastly, profitability had a positive effect as a moderating variable that strengthens the relationship between leverage with firm value. The results of this study are consistent with research conducted by [12]. A high level of profit makes the company's internal funds enough to meet investment needs. The company prefers internal funds from company's own capital, it shows that high profitability resulted in the company not need external funding company because the company's fund requirement is fulfilled. It aims to increase the value of the company in the eyes of investors. The results of this study support the pecking order theory which states that a high level of profit makes the company's internal funds enough to meet investment needs. Profitability as a moderating variable proved to be able to strengthen the relationship between leverage and firm value, which means that the lower the need for funds (debt) so that the lower the leverage ratio.

\section{CONCLUSIONS, IMPLICATIONS AND SUGGESTIONS}

\section{A. Conclusions}

There are several conclusions in the study. First, Corporate Social Responsibility had positive and insignificant effect to the firm value in Manufacturing Industry Sector of Consumer Goods Listed on BEI Period 2012-2015, even though the relationship is positive, CSR disclosure has little effect on value company. Level of influence of CSR seen from regression coefficient value that is equal to 0,089 . This is because the company has not fully followed the standards issued by GRI G3. Second, leverage had a positive and significant effect on the firm value in the Manufacturing Industry Sector of Consumer Goods which is listed on the Stock Exchange period of 2012-2015, because if the addition of debt of the company can increase the profit of the company, it will give a positive signal to the investor, will be interested to invest in the company.

Furthermore, profitability positively influenced as a moderating variable that proves able to strengthen the relationship between CSR and firm value in Manufacturing Companies of Consumer Goods Sector Listed on BEI Period 2012-2015, because companies with high profitability can increase CSR activity disclosure can improve company reputation. Last, profitability had positive effect as moderation variable which proved able to strengthen the relationship between leverage and firm value in Manufacturing Company of Consumer Goods Sectors Listed in IDX for 2012-2015 period. It was because high profitability resulted in the company not need external fund of company due to fund requirement of company fulfilled by internal funds. Thus, it aims to increase the value of the company in the eyes of investors.

\section{B. Implication of the study}

The findings have important implications for practitioners with respect to CSR disclosure in addressing firm value.

\section{Suggestion}

Suggestion of this research as follows: (1) The sample in this research is small so that feared cannot reflect the development of firm value as a whole. Therefore, it is hoped that further research can use broader research objects such as companies engaged in manufacturing companies or stateowned companies, in order to obtain a larger sample of research. (2) Based on Adjusted R Square result that is equal to $61,4 \%$, so it is expected for subsequent research can add or use other variable to know more any variable that can influence firm value. (3) The result of this research shows that CSR has positive and insignificant effect to firm value. This is because the company has not fully followed the GRI G3 standard in disclosing CSR. So, it is expected for the company, need to increase 


\section{CSR disclosure of GRI G3 standard to be able to increase firm value.}

\section{REFERENCES}

[1] R. Aziz, (2014). "Artikel Analisa Saham Fundamental" pada http://www.seputarforex.com/analisa/lihat.php?id=208100\&title=mari intip_saham_sektor_konsumsi_yang_menarik diunduh pada tanggal 06 Maret 2017.

[2] R. Kusumadilaga, (2010) "Pengaruh Corporate Social Responsibility Terhadap Nilai Perusahaan dengan Profitabilitas Sebagai Variabel Moderating Pada Perusahaan Manufaktur yang Terdaftar di BEI", Skripsi, Universitas Diponegoro, Semarang.

[3] A. Lako, (2011) "Dekonstruksi CSR \& Reformasi Paradigma Bisnis \& Akuntansi”. Erlangga. Jakarta.

[4] I Made Sudana, (2011) "Manajemen Keuangan Perusahaan Teori \& Praktik. Erlangga", Jakarta.

[5] Handriyani, (2013). "Pengaruh Corporate Social Responsibility Terhadap Nilai Perusahaan Dengan Profitabilitas Sebagai Variabel Moderating Pada Perusahaan Manufaktur yang Terdaftar di BEI", Jurnal Ilmu \& Riset Akuntansi vol. 2 No. 5.

[6] T. H. Handoko, (2013). "Manajemen", Edisi Kedua. BPFE-Yogyakarta. Yogyakarta.

[7] R. Wulandari, and Wirakusuma, (2016) "Dampak Moderasi Profitabilitas Terhadap Pengaruh Corporate Social Responsibility Pada Nilai Perusahaan Manufaktur Yang Terdaftar Di BEI”, E-Jurnal Ekonomi dan Bisnis Universitas Udayana 5.7, 1889-1918.
[8] N. Angrayani, (2016) "Pengaruh Pengungkapan Corporate Social Responsibility Dan Kepemilikan Manajerial Terhadap Nilai Perusahaan Dengan Profitabilitas Sebagai Variabel Moderating Pada Perusahaan Manufaktur di Indonesia Dan Singapura", Skripsi, Universitas Muhammadiyah, Yogyakarta.

[9] Poerwanto, (2010) Corporate Social Responsibility. Pustaka Pelajar. Yogyakarta.

[10] Pratama and Wiksuna, (2016) "Pengaruh Ukuran Perusahaan dan Leverage terhadap Nilai Perusahaan dengan Profitabilitas sebagai Variabel Mediasi”, e-Jurnal Manajemen Unud, vol. 5, No.2, pp.13381367.

[11] Brigham and Houston. (2009), Fundamentals of Financial Management, Edisi Sepuluh. Salemba Empat. Jakarta.

[12] D. Tamba, (2016) "Pengaruh Ukuran Perusahaan Dan Leverage Terhadap Nilai Perusahaan Dengan Profitabilitas Sebagai Variabel Moderasi Pada Perusahaan Barang Konsumsi Di BEI", Skripsi, Universitas Sumatera Utara, Medan.

[13] W. A. Setianingrum, (2015) "Pengaruh Corporate Social Responsibility Terhadap Nilai Perusahaan dengan Profitabilitas sebagai Variabel Moderasi pada Perusahaan Manufaktur yang Terdaftar di BEI Periode 2011-2013”, Skripsi, Universitas Negeri, Semarang.

[14] Chen, C. Y Roger and C. H. Lee, (2017) "The influence of CSR on firm value: an application of panel smooth transition regression on Taiwan”, Journal Applied Economics vol. 49, No. 34, pp.3422-3434.

[15] M. C. Cheng, and Z. C. Theng, (2011). "The Effect Leverage on Firm Value and How the Firm Financial Quality Influence on This Effect", World Journal of Management Vol. 3. No. 2, pp.30-53. 